\title{
Analysis of the Significant Factors on Nurse's Performance in the Ward at the Doctor Soepraoen Hospital Malang
}

\begin{abstract}
Nurse performance has an important role in healthcare and the continuity of hospital operations. For this reason, sufficient information is needed about the nurses requirements and the factors that influence them. Purpose of this study was to infestigate factors that were examined about the performance of nurses in the ward of Dr. Soepraoen Hospital. This is a quantitative study with a cross sectional design, which aims to measure independent variables and be approved at one time. The study sample was 166 nurses, using a questionnaire. Results showed that the most dominant factor had a comparison of the performance of nurses with $\beta$ values of 0.76 , work environment 0.51 , and leadership 0.21. Simultaneously in the regression model, research, research, compensation, variables, compensation, coefficient of 0.81 , work environment participation of 0.09 and leadership - 00.6. Researchers like a fairer compensation system through remuneration in order to motivate nurses to improve performance that will improve patient satisfaction in Dr. Soperaoen Hospital. These results indicate that there are differences between leadership, compensation and environmental variables with nurse performance, this means, facts that need attention from the hospital management to be able to improve nurse performance. The most dominant factor towards nurse performance is compensation, the expected system of recitation, incentives and honorariums have the greatest leverage in an effort to improve the performance of nurses in the inpatient care room of the Soepraoen Hospital Malang.
\end{abstract} nurse performance
Keywords: Leadership, compensation, work environment and

a

Published : May 10, 2020

\author{
Received: October 12, 2019
Accepted: February 13, 2020
}

(n)




\section{INTRODUCTION}

Leadership has a close relationship with employee performance. Employee performance is not only seen from skills but also seen from the way someone leads and influences his fellow workers to achieve profitable goals. A leader must be able to contribute to the predictions of empowering subordinates. In this case the head of the nurse unit is required to motivate the nursing staff so that they maintain their achievements in service to patients and can continue to produce effective performance results. The more often the head of the room gives direction and instructions, the better job satisfaction and performance of nurses at the Hospital. So the leader in the nursing unit must be able to bring himself (manage) to establish effective and therapeutic relationships with leaders and other health teams and be able to influence others to act in accordance with the plans that have been set. Effective and harmonious relationships can be done by the leader if the leader is able to influence or motivate subordinates to do what has been determined to achieve organizational goals.

Compensation is something that employees receive as a substitute for their service contribution to the company, this is also an important factor in efforts to improve employee performance and as an incentive in encouraging employees to achieve organizational goals. Appropriate compensation will encourage employees to work better and harder, so that organizational goals will be achieved. Hospital nurses, of course, are very desirable, where some of them mean that work is to produce money that can be used to meet their family's daily needs, because in fact the main purpose of most people is working to get compensation. So the existence of appropriate compensation can not only affect the material conditions of the employees, it will also reassure the employee to work more diligently and more initiative. If, giving compensation is not appropriate, of course it will disturb employees and reduce work enthusiasm, so that employee performance will decrease.

The implementation of nursing practice will be carried out professionally if it is supported by a professional nurse's working environment. there is a very large influence between the nurse's work environment and the implementation of nursing practice. Good working environment conditions can improve the quality of life in work which has an impact on the work productivity of good health professionals. Efforts that can be done to manage the nurse's work environment optimally are through empowering nurses to better understand and apply their ability to make decisions related to their practice in accordance with their authority responsibly and will have an impact on the realization of professional implementation of nursing practice.

\section{METHODS}

Hospital performance is largely determined by one of them is a nurse, besides the dominant number, the nurse has direct contact with the patient 24 hours a day. This study aims to determine the factors that influence the performance of nurses, to analyze the influence of perceptions of leadership, compensation and the work environment of nurses with inpatient nursing performance at the Level II Hospital of Dr. Soepraoen. This research is a quantitative study with a cross sectional design, which means the measurement of independent and bound variables is carried out at one time. The research sample was executive nurses totaling 166 people, using a questionnaire. The questionnaire used consisted of a questionnaire for the nursing nurse and for the ward head. Statistical test using Correlation Test and Multiple Regression. Before being deployed a validity and reliability test was carried out on 32 nurses at the Rumkit Tk III Lawang. Validity Results The results obtained from the validity and reliability of the questionnaire are: for leadership, compensation and environmental variables consisting of 37 questions having the smallest calculated $\mathrm{r}$ is LS7 $=0.3833$ and LS11 $=0.9295$, so all questionnaire questions are $>0.3494$. So it can be concluded that all the questionnaire question items are valid. While for the reliability test with Cronbach Alpha all variables have a value of 0.84862056 or (6 0.6) so the questionnaire used is Reliable. 


\section{RESULTS}

\section{Correlation}

$\begin{array}{lrrrr} & \text { KEP } & \text { LIN } & \text { KOM } & \text { KP } \\ \text { KOP } & 1 & & & \\ \text { LIN } & 0.415085 & 1 & & \\ \text { KOM } & 0.317245 & 0.624902 & 1 & \\ \text { KP } & \mathbf{0 . 2 2 5 8 6 9} & \mathbf{0 . 5 1 5 3 3 7} & \mathbf{0 . 7 6 0 1 8 5} & 1\end{array}$

The table above shows that the results of the correlation analysis between work life quality factors and nurse performance obtained a significance value of 0.001 , because the significance value was less than 0.05. According to Sugiyono (2007), the guidelines for providing interpretations of correlation coefficients are as follows: Very low $=0.00-0.199$, low $=0.20-0.399$, moderate $0.40-0.599$, strong $=0.60-0.799$, very strong $=0.80-1.00$. Judging from these interpretations, it can be concluded, that leadership factors have a low influence on nurse performance, while environmental factors have a moderate influence on nurse performance. For compensation factors have a strong correlation with nurse performance.

The analysis used to determine the effect of the variable quality of work life on the performance of nurses in this study is the analysis of Multiple Linear Regression.

\begin{tabular}{|l|r|}
\hline \multicolumn{2}{|c|}{ Regression Statistics } \\
\hline Multiple R & 0.762635907 \\
\hline R Square & 0.581613526 \\
\hline Adjusted R Square & 0.573865628 \\
\hline Standard Error & 2.643893919 \\
\hline Observations & 166 \\
\hline
\end{tabular}

The table above shows the strength of influence between models (independent variables) with the dependent variable. Number of observations that were processed by 166 observations. The standard error is an SE from the estimated bounded variants of 2.64. R Square (R2) or coefficient of determination, measures goodness or goodness of fit of the regression equation, with a value of 0.57 . Compound $\mathrm{R}$ value is a measure of the closeness level of the linear relationship between the dependent variable (nurse performance) and all independent variables (leadership, environment and compensation) together. The compound $\mathrm{R}$ value of 0.76 shows the relationship between free and bound variables in this model is strong.

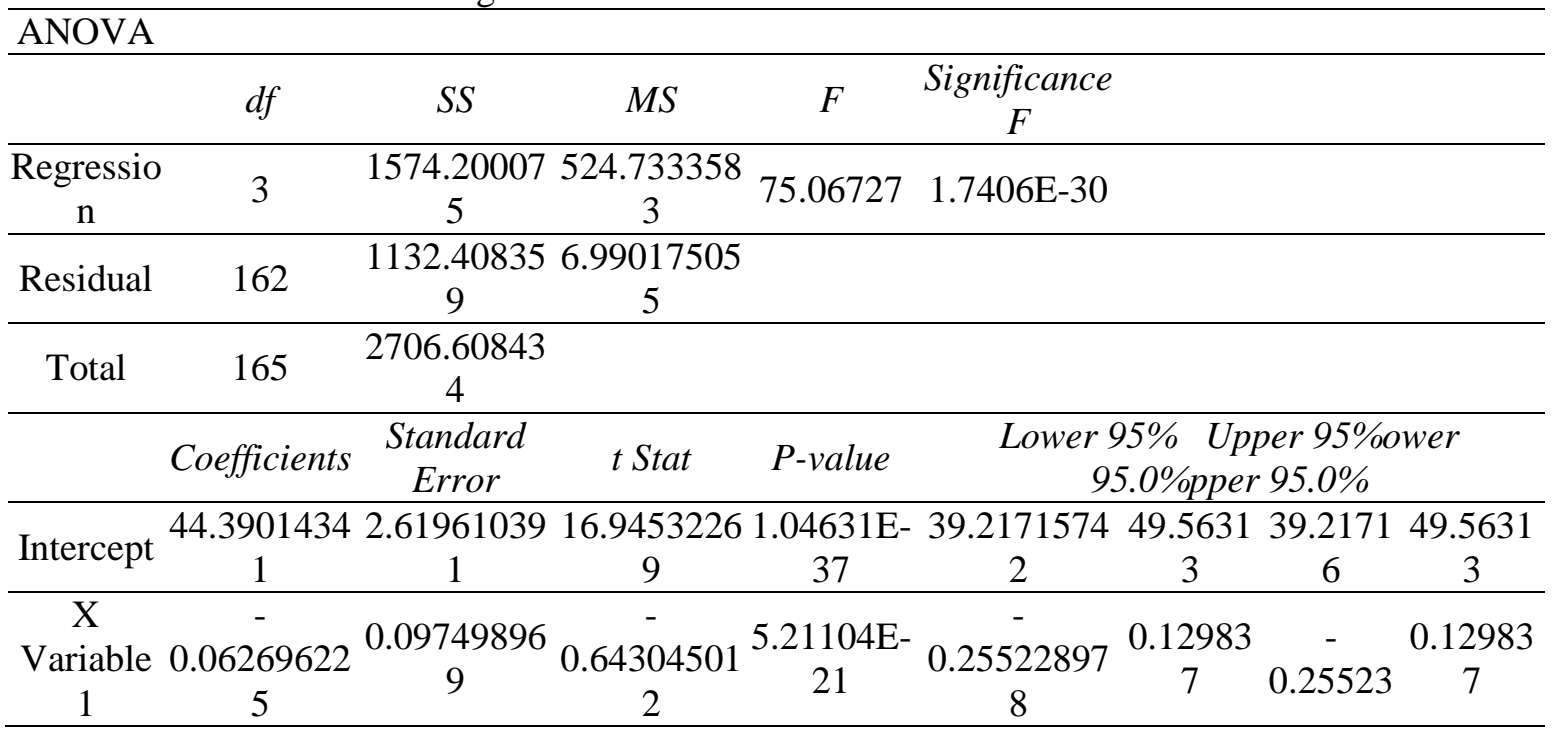




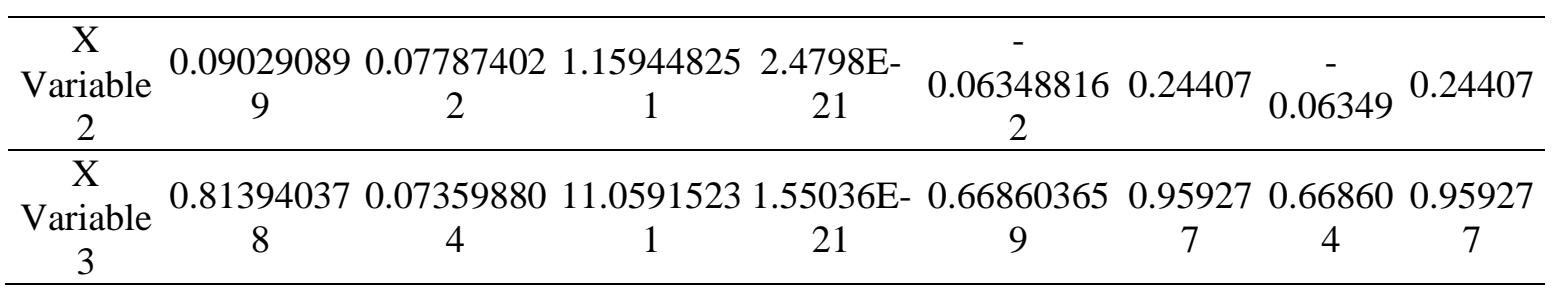

The table above shows the coefficient, SE, t-stat and p-value values of the model,based on the regression calculation above, the regression equation can be summarized as follows:

$$
K P=44,39+0,81 K O M+0,09 L I N-0,06 K E P
$$

From the function above shows there is a positive effect of compensation variables and the environment and the negative influence of leadership variables on nurse performance. The regression coefficient is positive, indicating that the direction of influence is positive, meaning that the better the compensation and the social environment of the nurse, the nurse's performance also increases. While the negative kooefficient shows the diminishing leadership value, the value of nurses' performance increases.

\section{DISCUSSION}

Characteristics of respondents in this study in general are Military Status 9 nurses (5.42\%), 29 civil servants nurses (17.47\%) and Sukwan 128 nurses (77.11\%). Position as Head of Room 10 nurses (6.02\%), CI 9 nurses (5.42\%), Team Leader 16 nurses (9.64\%) and Implementing Nurses 128 nurses (78.92\%). 1-2 years work period 17 people (10.24\%), 3-5 years 76 people (45.78\%), 6-10 years 34 people $(20.48 \%)$ and more than 10 years 39 people $(23.49 \%)$. While for the level of education Diploma 133 people $(80.12 \%)$ and Bachelor 33 people (19.88\%).

Leadership influences employee performance at Dr. Soepraoen-Malang Hospital, with a correlation value of 0.23 . Which means weakly correlated. These results indicate that the higher leadership pressure in Soepraoen Hospital further reduces nurse performance, and vice versa. Compensation has an effect on the performance of nurses at Dr. Soepraoen-Malang Hospital. Compensation correlation coefficient for nurse performance is 0.76. These results indicate the better the compensation of nurses in Soepraoen Hospital the better the performance, and vice versa. Work Environment influences the performance of nurses at Dr. Soepraoen-Malang Hospital with a coefficient of 0.52. These results indicate the better the work environment of nurses in Soepraoen Hospital the better the performance, and vice versa.

From the results of this study, it is proven that nurses who have less or less performance than nurses who have good performance, which needs improvement, especially on the quality of work life of nurses, as well as improvement in planning according to nursing care standards, discipline and craft and manners in carrying out nursing care for patients, possibly also because of the inconsistency of executive nurses and the head of the room in answering questions on the research questionnaire.

There are influences between the three factors of work quality of life (compensation, environment and leadership) with the performance of nurses, this means that the three factors need attention from the hospital management to improve nurse performance. The most dominant factor influencing the performance of nurses is compensation, meaning that the recitation system, incentives and honoraria have the greatest leverage in an effort to improve nurse performance.

\section{CONCLUSION}

It is proven that nurses who have good performance are greater than nurses who have less performance, but for the improvement of services still need improvement, especially on the quality of work life of the nurses, especially leadership, compensation and work environment. Nurses' perceptions of leadership and partial compensation are still lacking while for work environments most of the perceptions of implementing nurses are good 


\section{REFERENCES}

Anne Paula O'keeffe, Margarita Corry \& Debra K. Moser, 2015, Measuring job satisfaction of advanced nurse practitioners and advanced midwife practitioners in the Republic of Ireland: a survey (Journal of Nursing Management, 2015, 23, 107-117

Anggoro, A, 2006, Hubungan Komponen Quality Of Work Life dengan Produktivitas Perawat Ruang Rawat Inap Rumah Sakit Umum Fakultas Kedokteran Universitas Kristen Indonesia Tahun 2006, Tesis Program Studi Kajian Administrasi Rumah Sakit Pasca sarjana Universitas Indonesia.

Apeksha Gulavani \& Mahadeo Shinde, 2014, Occupational Stress and Job Satisfaction among Nurses (International Journal of Science and Research/IJSR, April 2014.

Barlian, Noer Aisyah, 2017, Faktor Determinan Kepemimpinan Dan Kepuasan Kerja Karyawan Klinik Husada Mulia Kabupaten Lumajang, ASSETA jurnal ilmiah ilmu-ilmu akutansi , keunagan dan pajak VOL 1 NO 2 (2017): JULY 2017

Carolina,L, 2006. Pengaruh Pelaksanaan Program Quality Of Work Life Terhadap Produktivitas Karyawan Di hotel Dyana Pura Seminyak Kuta Kabupaten BadungTahun2006.

Cascio Wayne F, 2010. Managing Human Resources, Productivity, Quality of Work Life, Profits, Eighth Edition, McGraw - Hill International Edition.

Ch. Platis P. Reklitis, S. Zimeras, 2015, Relation between job satisfaction and job performance in healthcare services, Procedia - Social and Behavioral Sciences 175, 2015, 480 - 487

Dewi, RP, 2010. Hubungan Pengetahuan Mengenai Akreditasi Rumah Sakit Dan Karakteristik Individu Dengan Kinerja perawat Rumah Sakit Zahirah Tahun 2010. Tesis Program Pasca Sarjana, FKM UI.

Emily A. Read \& Heather. Laschinger, 2015, The influence of authentic leadership and empowerment on nurses' relational social capital, mental health and job satisfaction over the first year of practice, Journal of Advanced Nursing, Publication 2 January 2015,

Fitrianasari, Dini, et. Al. , 2013, Pengaruh Kompensasi dan Kepuasan Kerja terhadap Organizational Citizenship Behavior (OCB) dan Kinerja Karyawan (Studi pada Perawat Rumah Sakit Umum "Darmayu" di Kabupaten Ponorogo), Fakultas Ilmu Administrasi Universitas Brawijaya Malang.

Haryati, Made Ayu, 2012, , Tesis, Program Pasca Sarjana, Program Studi Kajian Administrasi Rumah Sakit, Fakultas Kesehatan Masyarakat, Universitas Indonesia. Hubungan Kualitas Kehidupan Kerja Dengan Kinerja Perawat ,Pelaksana di Rumah Sakit Bali Med Denpasar

Jyoti Sharma \& Rajib Lochan Dhar, 2016, Factors influencing job performance of nursing staff Mediating role of affective commitment (Personnel Review Vol. 45 No. 1, 2016 pp. 161-182

Kuanto A, 2010. Hubungan Komponen Quality Of Work Life Dengan Kinerja Perawat Di Ruang Rawat Inap Rumah Sakit Bhakti Yudha Depok Tahun 2010. Tesis Program Pasca Sarjana,

FKM UI.

Kurniasari, L. 2005. Pengaruh Komitmen Organisasi dan Job Insecurity Karyawan Terhadap Intensi Turnover. http://www.damandiri.or.id. 
Mahdieh Arian, Mohsen Soleimani, \& Mohammad Bagher Oghazian2018, Job satisfaction and the factors affecting satisfaction in nurse educators: A systematic review (Journal of Professional Nursing Vol. 34, Issue 5, September-October 2018, Pages 389-399)

Mohammad Alhamwan, Norazuwa Bt Mat \& Imad Al Muala, 2015, The Impact of Organizational Factors on Nurses Turnover Intention Behavior at Public Hospitals in Jordan: How Does Leadership, Career Advancement and Pay-Level Influence the Turnover Intention Behavior among Nurses (Journal of Management and Sustainability; Vol. 5, No. 2; 2015

Posuma, Christilia O., 2013, Kompetensi, Kompensasi, Dan Kepemimpinan Pengaruhnya Terhadap Kinerja Karyawan Pada Rumah Sakit Ratumbuysang Manado, Jurnal Emba: Jurnal Riset Ekonomi, Manajemen, Bisnis Dan Akuntansi Vol 1, No 4 (2013)

Prihanjana. I, 2010. Rekomendasi Menurunkan Turn Over Rate Rumah Sakit Bali Med Denpasar Dengan Menggunakan Faktor Pendorong Dan Penarik.

Purnama Sari, Ayu Tri , 2016, Ruang Dengan Kinerja Perawat Di Ruang Rawat Inap Kelas Iii RSUD Muntilan Kabupaten Magelang, Naskah Publikasi, Program Studi Ilmu Keperawatan Fakultas Ilmu Kesehatan, Universitas ‘Aisyiyah, Yogyakarta

Putra, KR, Achir Yani S. Hamid, Mustikasari, 2007, The Influence Of Nurses' Working Environment To Implementation Nursing Practice In General Hospital Dr. Saiful Anwar Malang Year 2006, Jurnal Kedokteran Brawijaya, Vol. XXIII, No. 1, April 2007

Royani, 2010, Hubungan Sistem Penghargaan Dengan Kinerja Perawat Dalam Melaksanakan Asuhan Keperawatan Di Rumah Sakit Umum Daerah Cilegon Banten, Magister Ilmu Keperawatan Kekhususan Kepemimpinan Dan Manajemen Keperawatan Program Pasca Sarjana Fakultas Ilmu Keperawatan Universitas Indonesia

Saleh, Abbas, et. Al. , 2016, Factors Affecting The Job Satisfaction And Performance Of Nurses Private Hospitals Class B In Makassar, International Journal Of Scientific \& Technology Research Volume 5, Issue 10, October 2016

Wening, N. 2005. Pengaruh Ketidak Amanan Kerja (Job Insecurity) Sebagai Dampak Restrukturisasi Terhadap Kepuasan Kerja, Komitmen Organisasi dan Intensi keluar Survivor. Empirika. Vol. 18.

Widyatmini \& Luqman Hakim, 2012, Hubungan Kepemimpinan, Kompensasi Dan Kompetensi Terhadap Kinerja Pegawai Dinas Kesehatan Kota Depok, Jurusan Manajemen, Fakultas Ekonomi, Universitas Gunadarma 